\title{
MENINGKATKAN PEMAHAMAN KONSEP BANGUN RUANG MAHASISWA CALON GURU SEKOLAH DASAR MENGGUNAKAN GAME ANDROID
}

\author{
Muhammad Erfan \& Mohammad Archi Maulyda \\ Universitas Mataram \\ muhammaderfan@unram.ac.id; archimaulyda@unram.ac.id
}

\begin{abstract}
This study aims to improve the conceptual understanding of prospective elementary school teacher students on the concept of geometrical space which includes the relationship between lines and planes as well as lines and lines in geometrical space using Android games. The Android game used was XSection. This research is a quasi-experimental study with a pretest-posttest control group design. The sample in this study was taken using cluster random sampling technique and obtained class $3 \mathrm{C}$ as an experimental class, namely the class that learns using Android-based educational games and $3 D$ class as the control class, namely the class that learns without using Android-based educational games. Data regarding conceptual understanding were obtained by multiple choice test and data were analyzed using independent sample t-test and normalized gain test. The results showed that the experimental class showed a significant increase in understanding the concept of geometrical space compared to the control class. The post-test average score of students' concepts understanding in the experimental class was higher than the control class so that the Android-based education game was effective in improving students' understanding of the concept of geometrical space for prospective elementary school teacher.
\end{abstract}

Keywords: Concept, Geometry, Math, Games, Android

\begin{abstract}
Abstrak : Penelitian ini bertujuan untuk meningkatkan pemahaman konsep mabasiswa calon guru sekolah dasar pada materi konsep bangun ruang yang meliputi bubungan antara garis dan bidang serta garis dan garis dalam ruang, serta ketegaklurusan garis terbadap bidang menggunakan game edukasi berbasis Android. Game Android yang digunakan adalah XSection. Penelitian ini merupakan penelitian kuasi eksperimen dengan pretest-posttest control group design. Sampel pada penelitian ini diambil dengan teknik cluster random sampling dan diperoleh kelas $3 C$ sebagai kelas eksperimen yaitu kelas yang belajar dengan menggunakan game edukasi berbasis Android XSection dan kelas 3D sebagai kelas kontrol yaitu kelas yang belajar tanpa menggunakan game edukasi berbasis Android. Data mengenai pemabaman konsep diperoleb dengan teknik tes dan data dianalisis dengan uji-t independent sample dan uji gain ternormalisasi. Hasil penelitian menunjukkan babwa kelas kelas eksperimen menunjukekan peningkatan pemabaman konsep bangun ruang yang signifikan dibandingkan kelas kontrol. Nilai rata-rata post-test pemahaman konsep mahasiswa pada kelas eksperimen lebih tinggi daripada kelas kontrol sehingga game edukasi berbasis Android efektif dalam meningkatkan pemahaman konsep bangun ruang mahasiswa calon guru sekolah dasar.
\end{abstract}

Kata Kunci: Konsep, Geometri, Matematika, Game, Android

PALAPA : Jurnal Studi Keislaman dan Ilmu Pendidikan

https:/ / ejournal.stitpn.ac.id/index.php/palapa 


\section{PENDAHULUAN}

Kemajuan Ilmu Pengetahuan dan Teknologi (IPTEK) dalam bidang Teknologi Informasi (TI) yang semakin hari semakin canggih tentunya membawa berbagai dampak. Dampak yang ditimbulkan dapat berupa dampak positif dan dampak negatif. Dampak positif dari perkembangan teknologi informasi adalah cepatnya akses informasi yang dapat diterima seseorang karena adanya komunikasi melalui internet, mempermudah pembelajaran jarak jauh serta dapat menyediakan berbagai konten baik konten hiburan, pembelajaran maupun konten permainan melalui gadget yang memiliki daya portabilitasnya yang tinggi (Rosiyanti \& Muthmainnah, 2018). Dampak negatif yang dapat ditimbulkan karena penggunaan gadget adalah kecenderungan pengguna dalam mengakses konten negatif (Prihandini et al., 2019; Rachmaniar et al., 2018), terlalu mengandalkan gadget, serta dapat menimbulkan rasa malas untuk berpikir lebih keras (Pritandhari, 2018).

Gadget bagi generasi milenial merupakan barang yang tidak dapat dipisahkan dalam kehidupan sehari-hari. Emarketer sebagai salah satu lembaga riset di bidang digital marketing mencatat bahwa di tahun 2018, banyaknya pengguna smartphone aktif di Indonesia lebih dari 150 juta orang, di tahun 2019 naik menjadi lebih dari 190 juta orang. Indonesia menjadi negara keempat pengguna aktif smartphone di dunia setelah China, India dan Amerika (Nirwana et al., 2018), serta sebagian besar warga Indonesia menghabiskan waktunya dengan bermain gadget atau smartphone (Amin, 2014).

Berdasarkan hasil survei yang dilakukan oleh Nusaresearch di tahun 2017 mengenai penggunaan mobile game di Indonesia diketahui bahwa dari 518 responden, 99,6\% menggunakan Operating System Android di smartphonenya, serta semua responden $(100 \%)$ menggunakan waktu senggangnya untuk bermain game di smartphone Android. Berdasarkan hasil survei tersebut juga diinformasikan bahwa 50,6\% responden menganggap bermain game di gadget adalah sebuah hobi dan 34\% dari responden ratarata menghabiskan waktu 20 hingga 30 menit bermain game (Nusaresearch, 2017).

Banyaknya pengguna gadget khususnya kalangan remaja yang menggunakan gawainya untuk bermain game tentunya menimbulkan distraksi bagi penggunanya (Amalia et al., 2018; Oktavia \& Mulabbiyah, 2019; Syahyudin, 2019), penggunaan gadget yang berlebihan dapat menimbulkan kecanduan, banyak waktu yang dihabiskan hanya 
untuk bermain game dan ini tentunya dapat mengganggu kegiatan proses belajar peserta didik. Pendidik dan orang tua tentunya tidak hanya mengawasi peserta didik dalam penggunaan gadget yang berlebihan tetapi orang tua dan pendidik juga diharapkan mencari jalan lain agar pengguna gadget khususnya para remaja lebih berorientasi pada kegiatan belajarnya daripada bermain game atau dengan mengintegrasikan kontenkonten pendidikan ke dalam suatu permainan digital atau Digital Game-Based Learning (Erfan et al., 2020; Erfan \& Ratu, 2017).

Digital Game-Based Learning merupakan salah satu metode pembelajaran yang menggabungkan konten pendidikan atau prinsip-prinsip pembelajaran ke dalam video game dengan tujuan untuk melibatkan peserta didik secara aktif dalam kegiatan pembelajaran (Coffey, 2017). Digital Game-Based Learning dapat digunakan pendidik untuk mendukung peserta didik dalam mengembangkan berbagai keterampilan (Serrano, 2019). Belajar melalui permainan berpengaruh positif terhadap motivasi peserta didik dalam belajar (Chen, 2017; Erhel \& Jamet, 2013; Yeh et al., 2017; Yusny, 2013),

Dengan adanya pandemi covid-19 yang membuat warga harus melakukan social distancing dan banyaknya peserta didik yang sudah memiliki gadget berupa smartphone yang mendukung dalam kegiatan belajar dalam jaringan (daring) maka kegiatan belajar melalui permainan digital bisa dilakukan agar materi-materi yang wajib untuk disampaikan oleh pendidik (dosen) dapat dipahami dan diterima dengan baik oleh peserta didik (mahasiswa) calon guru sekolah dasar.

Salah satu materi yang wajib dikuasai calon guru sekolah dasar dalam mata kuliah Pendidikan Matematika Sekolah Dasar adalah mengenai konsep bangun ruang, pada mata kuliah ini diajarkan berbagai konsep mengenai hubungan antara garis dengan garis apakah berpotongan atau sejajar, hubungan antara garis dan bidang yang meliputi garis yang menembus bidang atau garis yang sejajar dengan bidang. Berdasarkan hasil kuis yang diberikan oleh pendidik (dosen) kepada salah satu kelompok mahasiswa semester III (tiga) program studi pendidikan guru sekolah dasar di salah satu perguruan tinggi di Nusa Tenggara Barat ditemukan bahwa masih banyak peserta didik (mahasiswa) yang belum menguasai konsep-konsep dasar mengenai bangun ruang. Mengingat sifat materi mengenai bangun ruang wajib dikuasai oleh mahasiswa calon guru sekolah dasar maka 
penelitian ini bertujuan untuk meningkatkan pemahaman mahasiswa mengenai konsep bangun ruang menggunakan permainan atau game Android.

\section{METODE PENELITIAN}

Penelitian ini merupakan penelitian kuantitatif dengan pendekatan eksperimen semu atau kuasi eksperimen. Desain penelitian yang digunakan adalah pretest-posttest control group. Penelitian ini bertujuan untuk meningkatkan pemahaman konsep mahasiswa calon guru sekolah dasar pada materi konsep bangun ruang yang meliputi hubungan antara garis dan bidang serta garis dan garis dalam ruang, serta ketegaklurusan garis terhadap bidang menggunakan game edukasi berbasis Android. Game Android yang digunakan adalah XSection yang dapat di unduh secara gratis di Play Store.

Populasi pada penelitian ini adalah seluruh mahasiswa calon guru sekolah dasar semester tiga di salah satu perguruan tinggi negeri di Kota Mataram yang berjumlah 284 orang mahasiswa. Teknik pengambilan sampel yang digunakan adalah cluster random sampling dan diperoleh kelas 3C (32 mahasiswa) sebagai kelas eksperimen yaitu kelas yang belajar konsep bangun ruang dengan game edukasi XSection, dan kelas 3D (39 mahasiswa) sebagai kelas kontrol yaitu kelas konvensional yang belajar konsep bangun ruang tanpa menggunakan game Android XSection. Data mengenai pemahaman konsep bangun ruang mahasiswa diperoleh dengan tes pilihan ganda. Data pada penelitian ini selain dianalisis dengan uji-t sampel independen.

\section{HASIL DAN PEMBAHASAN}

Sebelum dilakukan perlakuan terlebih dahulu dilakukan uji awal atau pretest untuk melihat sejauh mana atau baru sampai di mana konsep mengenai bangun ruang yang sudah dikuasai oleh peserta didik calon guru sekolah dasar. Selanjutnya dilakukan uji prasyarat analisis pada nilai pretest untuk mengetahui apakah data nilai pemahaman konsep bangun ruang mahasiswa berdistribusi normal dan kedua kelas (eksperimen dan kontrol) memiliki varian data yang sama (homogen). Hasil pretest pemahaman konsep bangun ruang mahasiswa calon guru sekolah dasar disajikan pada Tabel 1. 
Tabel 1. Rata-rata Nilai Pretest pada Kelas Kontrol dan Kelas Eksperimen

\begin{tabular}{lllll}
\hline Kelas & Rata-rata & Normalitas & Homogenitas & Signifikansi \\
\hline Eksperimen & 53,75 & Sig. 0,277 $>0,05$ & Sig. 0,866 $>0,05$ & t-hitung $<$ t-tabel \\
Kontrol & 52,56 & Sig. 0,099 $>0,05$ & & $0,340<1,994$ \\
& & & Sig. (2-tailed) \\
& & $0,735>0,05$ \\
& & & Tidak berbeda \\
& & & signifikan \\
\hline
\end{tabular}

Kemampuan awal pemahaman konsep mahasiswa calon guru sekolah dasar pada materi bangun ruang sebagaimana ditunjukkan pada Tabel 1 diketahui bahwa nilai ratarata pretest mahasiswa di kelas eksperimen adalah sebesar 53,75 dan kelas kontrol sebesar 52,56. Berdasarkan hasil uji Normalitas pada Tabel 1 juga diketahui bahwa nilai signifikansi Shapiro-Wilk pada kelas eksperimen adalah 0,277 yang lebih besar dari 0,05 dan untuk kelas kontrol diperoleh nilai signifikansi (Sig. 0,099>0,05). Kedua nilai signifikansi tersebut menunjukkan bahwa data nilai pretest pemahaman konsep awal mahasiswa calon guru sekolah dasar pada materi konsep bangun ruang semuanya berdistribusi normal. Hasil uji homogenitas untuk melihat apakah nilai pretest pada kelas eksperimen maupun kelas kontrol memiliki varian yang sama, juga diperoleh nilai signifikansi di atas 0,05 (Sig. 0,866 > 0,05) yang berarti bahwa data kemampuan awal (pretest) mahasiswa calon guru sekolah dasar antara kedua kelas (eksperimen dan kontrol) memiliki varian atau ragam data yang sama atau homogen.

Untuk melihat apakah terdapat perbedaan yang signifikan pada nilai rata-rata kedua kelas dilakukan uji-t independent sample pada data pretest dan hasilnya menunjukkan bahwa nilai t-hitung kurang dari nilai t-tabel $(0,340<1,994)$ dan nilai Sig $(2$-tailed) yang diperoleh adalah 0,735 lebih besar dari 0,05 yang berarti bahwa tidak terdapat perbedaan signifikan pada nilai rata-rata pretest pemahaman konsep calon guru sekolah dasar antara kelas eksperimen maupun kelas kontrol pada materi konsep bangun ruang.

Setelah diberikan perlakuan berupa pembelajaran Matematika pada materi konsep bangun ruang yang melibatkan kemampuan peserta didik dalam mengenali hubungan antara garis dan bidang serta garis dan garis dalam ruang, serta ketegaklurusan 
garis terhadap bidang dengan menggunakan Game Android XSection, dilakukan posttest untuk melihat apakah terdapat peningkatan kemampuan peserta didik dalam memahami konsep bangun ruang. Hasil posttest kemampuan mahasiswa calon guru sekolah dasar setelah diberikan perlakuan disajikan pada Tabel 2.

Tabel 2. Rata-rata Nilai Posttest pada Kelas Kontrol dan Kelas Eksperimen

\begin{tabular}{lllll}
\hline Kelas & Rata-rata & Normalitas & Homogenitas & Signifikansi \\
\hline Eksperimen & 81,64 & Sig. 0,190 $>0,05$ & Sig. 0,091 $>0,05$ & t-hit $>$ t-tabel \\
Kontrol & 59,04 & Sig. $0,162>0,05$ & $8,568>1,994$ \\
& & & Sig. (2-tailed) \\
& & & $0,000<0,05$ \\
& & & Berbeda \\
& & & signifikan \\
\hline
\end{tabular}

Berdasarkan Tabel 2 diketahui bahwa terdapat perbedaan nilai rata-rata antara kedua kelas (kelas eksperimen dan kelas kontrol) dimana rata-rata nilai posttest pada kelas eksperimen adalah 81,64 dan rata-rata nilai posttest pada kelas kontrol adalah 59,04. Untuk melihat apakah perbedaan kedua nilai posttest ini signifikan atau tidak, digunakan uji-t independent sample dan hasilnya sesuai dengan Tabel 2 yaitu nilai t-hitung lebih besar dari t-tabel $(8,568>1,994)$. Berdasarkan hasil uji-t tersebut menunjukkan bahwa terdapat perbedaan yang signifikan antara kelas yang belajar dengan Game Android XSection (kelas eksperimen) dan kelas yang belajar secara konvensional (kelas kontrol).

Perbandingan hasil capaian peserta didik (mahasiswa) dalam pemahaman konsep bangun ruang baik pada pretest maupun posttest di kelas eksperimen maupun kelas kontrol disajikan pada Gambar 1. 


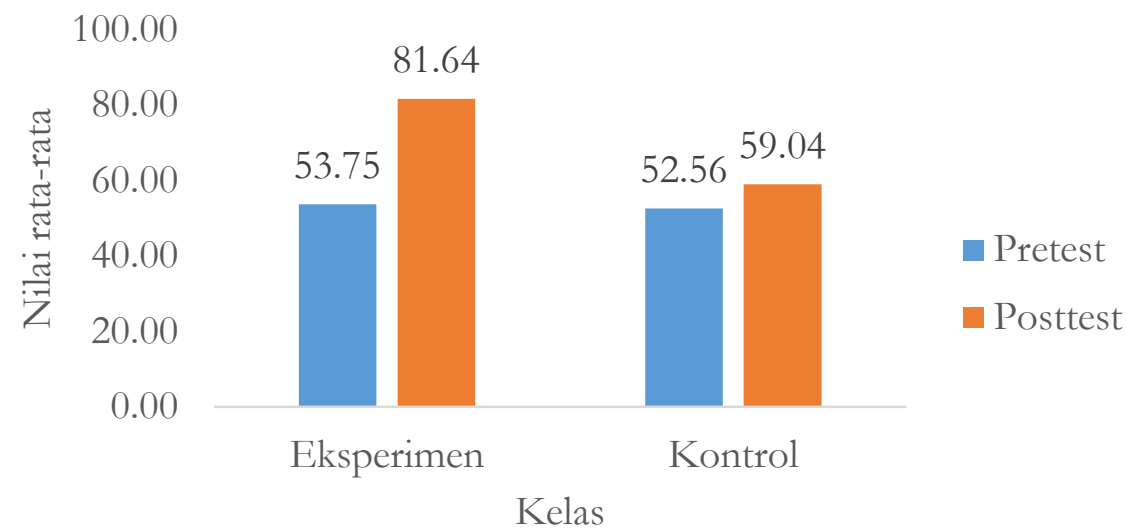

Gambar 1. Perbandingan hasil pretest dan posttest mahasiswa pada pemahaman konsep bangun ruang

Berdasarkan Gambar 1 dapat diketahui bahwa kedua kelas sebenarnya samasama mengalami peningkatan pemahaman konsep bangun ruang, namun peningkatan pemahaman konsep bangun ruang mahasiswa calon guru sekolah dasar pada kelas eksperimen lebih tinggi dibandingkan dengan peningkatan pemahaman konsep bangun ruang mahasiswa pada kelas kontrol. Meningkatnya pemahaman konsep bangun ruang pada kelas eksperimen juga dikuatkan oleh hasil uji-t pada nilai posttest kedua kelas (eksperimen dan kontrol) di mana t-hitung lebih besar dari t-tabel dengan t-hitung sebesar 8,568 dan t-tabel sebesar 1,994 pada taraf signifikansi 5\%. Hasil uji-t ini mengindikasikan bahwa terdapat perbedaan yang signifikan antara nilai rata-rata pemahaman konsep bangun ruang mahasiswa calon guru sekolah dasar setelah diberikan perlakuan pada kedua kelas (kelas eksperimen dan kelas kontrol). Berdasarkan Gambar 1 juga diketahui bahwa kelas eksperimen mengalami peningkatan nilai rata-rata yang lebih tinggi daripada kelas kontrol. Hal ini menunjukkan bahwa pembelajaran Matematika pada mahasiswa calon guru sekolah dasar berbantuan Game Android XSection memberikan dampak positif terhadap pemahaman konsep mahasiswa calon guru sekolah dasar pada materi konsep bangun ruang.

Belajar konsep bangun ruang melalui Game Android XSection lebih mampu meningkatkan kemampuan pemahaman konsep mahasiswa calon guru sekolah dasar pada materi bangun ruang dikarenakan pada game ini, mahasiswa dapat sekaligus mencoba secara virtual atau mahasiswa dapat mensimulasikan bagaimana suatu garis 
dapat berpotongan dengan garis yang lain pada bangun ruang kubus, prisma, serta piramida. Game Android XSection berperan sebagai laboratorium virtual di mana mahasiswa dapat mensimulasikan dan mempraktikkan bagaimana kedudukan suatu garis terhadap bidang maupun kedudukan garis terhadap garis lainnya pada bangun ruang. Penelitian ini sejalan dengan hasil penelitian lain di mana belajar melalui simulasi berbantuan laboratorium virtual terbukti mampu meningkatkan pemahaman konsep peserta didik (Aşıksoy \& Islek, 2017; Maulidah \& Prima, 2018; Pearlman et al., 2009, 2009; Suryanti et al., 2019), pembelajaran dengan permainan juga memberikan dampak yang positif bagi pengetahuan saintifk peserta didik (Liu \& Chen, 2013).

\section{KESIMPULAN}

Berdasarkan hasil penelitian dan pembahasan dapat disimpulkan bahwa terdapat perbedaan yang signifikan antara nilai rata-rata pemahaman konsep mahasiswa calon guru sekolah dasar dalam materi konsep bangun ruang setelah belajar dengan permainan atau Game Android XSection. Penggunaan Game Android XSection dalam proses pembelajaran Matematika Sekolah Dasar efektif dalam meningkatkan pemahaman konsep bangun ruang mahasiswa calon guru sekolah dasar.

\section{DAFTAR PUSTAKA}

Amalia, A., Rachman, A. A. R., Handayani, S. N., \& Rostikawati, Y. (2018). Dampak Penggunaan Gawai Terhadap Hasil Belajar Mahasiswa IKIP Siliwangi Bandung. PAROLE (JURNAL PENDIDIKAN BAHASA DAN SASTRA INDONESIA), 1(2), 157-164.

Amin, K. (2014). Indonesians spend most time on smartphones in the world. The Jakarta Post.

Aşıksoy, G., \& Islek, D. (2017). The Impact of the Virtual Laboratory on Students' Attitude in a General Physics Laboratory. International Journal of Online Engineering (IJOE), 13(04), 20. https://doi.org/10.3991/ijoe.v13i04.6811

Chen, Y.-C. (2017). Empirical Study on the Effect of Digital Game-Based Instruction on Students' Learning Motivation and Achievement. EURASLA Journal of Mathematics, Science and Technology Education, 13(7). https://doi.org/10.12973/eurasia.2017.00711a

Coffey, H. (2017). Digital game-based learning. http://www.learnnc.org/lp/pages/4970

Erfan, M., \& Ratu, T. (2017). Meningkatkan Minat Dan Hasil Belajar Mahasiswa Pada 
Perkuliahan Elektronika Dasar Melalui Digital Game-Based Learning. Meningkatkan Minat Dan Hasil Belajar Mahasiswa Pada Perkuliahan Elektronika Dasar Melalui Digital Game-Based Learning, 332-337. https://doi.org/S0962-8924(12)00067-0 [pii] \n10.1016/j.tcb.2012.04.004

Erfan, M., Widodo, A., Umar, U., Radiusman, R., \& Ratu, T. (2020). Pengembangan Game Edukasi Kata Fisika Berbasis Android untuk Anak Sekolah Dasar pada Materi Konsep Gaya. Lectura: Jurnal Pendidikan, 11(1), 31-46.

Erhel, S., \& Jamet, E. (2013). Digital game-based learning: Impact of instructions and feedback on motivation and learning effectiveness. Computers \& Education, 67, 156167. https://doi.org/10.1016/j.compedu.2013.02.019

Liu, E. Z. F., \& Chen, P.-K. (2013). The Effect of Game-Based Learning on Students' Learning Performance in Science Learning - A Case of "Conveyance Go." Procedia - Social and Behavioral Sciences, 103, 1044-1051. https://doi.org/10.1016/j.sbspro.2013.10.430

Maulidah, S. S., \& Prima, E. C. (2018). Using Physics Education Technology as Virtual Laboratory in Learning Waves and Sounds. Journal of Science Learning, 1(3), 116. https:// doi.org/10.17509/jsl.v1i3.11797

Nirwana, N., Mappapoleonro, A. M., \& Chairunnisa, C. (2018). The Effect of Gadget Toward Early Childhood Speaking Ability. Indonesian Journal of Early Childhood Education Studies, 7(2), 85-90. https://doi.org/10.15294/IJECES.V7I2.28548

Nusaresearch. (2017). Mobile Games Trend in Indonesia 2017. Macromill South East Asia. https://nusaresearch.com/sample/voluntary_surveys/detail.php?ID=90

Oktavia, N., \& Mulabbiyah, M. (2019). Gawai dan Kompetensi Sikap Sosial Siswa MI (Studi Kasus pada Siswa Kelas V MIN 2 Kota Mataram). El Midad, 11(1), 19-40. https://doi.org/10.20414/elmidad.v11i1.1903

Pearlman, R. S., Cummings, P. J., Shingles, R., Maldarelli, G. A., Horner, R. D., Hartmann, E. M., \& Obom, K. M. (2009). Virtual Lab Demonstrations Improve Students' Mastery of Basic Biology Laboratory Techniques. Journal of Microbiology \& Biology Education, 10(1), 51-57. https://doi.org/10.1128/jmbe.v10.99

Prihandini, P., Limilia, P., \& Pratamawaty, B. B. (2019). Generasi Cerdas Tanpa Pornografi: Penyuluhan Pencegahan Konsumsi Pornografi Media Digital di SMP Negeri 2 Bandung. Jurnal Dedikasi Masyarakat, 2(2), 75-82.

Pritandhari, M. (2018). Analisis Intensitas Penggunaan Gadget dan Pemanfaatan Internet Terhadap Motivasi Belajar. Jurnal Promosi, 6(1), 20-27.

Rachmaniar, R., Prihandini, P., \& Janitra, P. A. (2018). Perilaku Penggunaan Smartphone dan Akses Pornografi di Kalangan Remaja Perempuan. Jurnal Komunikasi Global, 7(1), 1-11.

Rosiyanti, H., \& Muthmainnah, R. N. (2018). Penggunaan Gadget Sebagai Sumber Belajar Mempengaruhi Hasil Belajar pada Mata Kuliah Matematika Dasar. FIBONACCI: Jurnal Pendidikan Matematika Dan Matematika, 4(1), 25. https://doi.org/10.24853/fbc.4.1.25-36

Serrano, K. (2019). The effect of digital game-based learning on student learning: A literature review. 
Suryanti, E., Fitriani, A., Redjeki, S., \& Riandi, R. (2019). Virtual laboratory as a media to improve the conceptual mastery of molecular biology. Journal of Physics: Conference Series, 1317, 012202. https://doi.org/10.1088/1742-6596/1317/1/012202

Syahyudin, D. (2019). Pengaruh Gadget Terhadap Pola Interaksi Sosial dan Komunikasi Siswa. GUNAHUMAS: Jurnal Kehumasan, 2(1), 272-282.

Yeh, Y.-T., Hung, H.-T., \& Hsu, Y.-J. (2017). Digital Game-Based Learning for Improving Students' Academic Achievement, Learning Motivation, and Willingness to Communicate in an English Course. 2017 6th ILAI International Congress on Advanced Applied Informatics (IIAI-AAI), 560-563. https://doi.org/10.1109/IIAI-AAI.2017.40

Yusny, R. (2013). The Influence of Digital Games Based Learning on Students' Learning Outcomes and Motivation. Register Journal, 6(2), 77. https://doi.org/10.18326/rgt.v6i2.77-100 